\title{
Challenges in the Diagnosis and Management of Bacterial Lung Infections in Solid Organ Recipients: A Narrative Review
}

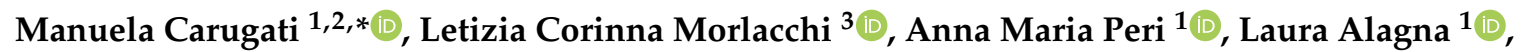 \\ Valeria Rossetti ${ }^{3}$, Alessandra Bandera ${ }^{1,4}$, Andrea Gori ${ }^{1,4,5}$, Francesco Blasi ${ }^{3,4}(\mathbb{D}$ and \\ on behalf of the IFALT Working Group ${ }^{\dagger}$ \\ 1 Internal Medicine Department, Division of Infectious Diseases, Fondazione IRCCS Cà Granda Ospedale \\ Maggiore Policlinico Milano, 20122 Milano, Italy; anninaperi@gmail.com (A.M.P.); \\ laura.alagna@policlinico.mi.it (L.A.); alessandra.bandera@unimi.it (A.B.); andrea.gori@unimi.it (A.G.) \\ 2 Division of Infectious Diseases and International Health, Duke University, Durham, NC 27710, USA \\ 3 Internal Medicine Department, Respiratory Unit and Adult Cystic Fibrosis Center, \\ Fondazione IRCCS Cà Granda Ospedale Maggiore Policlinico Milano, 20122 Milano, Italy; \\ letizia.morlacchi@gmail.com (L.C.M.); valeria.rossetti@policlinico.mi.it (V.R.); francesco.blasi@unimi.it (F.B.) \\ 4 Department of Pathophysiology and Transplantation, Università degli Studi di Milano, 20122 Milano, Italy \\ 5 Centre for Multidisciplinary Research in Health Science, 20122 Milano, Italy \\ * Correspondence: manuela.carugati@duke.edu \\ + Members are listed at the Acknowledgments.
}

Received: 19 November 2019; Accepted: 7 February 2020; Published: 12 February 2020

\begin{abstract}
Respiratory infections pose a significant threat to the success of solid organ transplantation, and the diagnosis and management of these infections are challenging. The current narrative review addressed some of these challenges, based on evidence from the literature published in the last 20 years. Specifically, we focused our attention on (i) the obstacles to an etiologic diagnosis of respiratory infections among solid organ transplant recipients, (ii) the management of bacterial respiratory infections in an era characterized by increased antimicrobial resistance, and (iii) the development of antimicrobial stewardship programs dedicated to solid organ transplant recipients.
\end{abstract}

Keywords: solid organ transplants; respiratory infections; pneumonia

\section{Introduction}

In the last decades, the introduction of effective immunosuppressive agents has reduced the risk of rejection of transplanted organs; nonetheless, the long-term immunosuppressive state of solid organ transplant recipients (SOTRs) has increased their susceptibility to infections, especially lung infections. Management of lung infections in SOTRs is complex: the spectrum of pathogens possibly involved is broad, infections can progress rapidly even though signs and symptoms are often mild, and antimicrobial resistance is widespread [1]. In particular, lung infections currently represent a leading cause of morbidity and mortality among SOTRs and threaten the success of transplantation [2].

The severity of lung infections in SOTRs is increased by several factors. First, the rapid and accurate identification of the causative pathogens of lung infections is critical for the appropriate therapeutic management of patients and to avert fatal outcomes. Unfortunately, conventional microbiology is characterized by suboptimal diagnostic accuracy, and few studies have attempted to describe the etiologic distribution of lung infections in SOTRs [3]. Second, the adverse outcomes associated with lung infections in SOTRs have led to the common use of prolonged courses of broad-spectrum antimicrobial agents in SOTRs. Though well intended, overuse of antibiotics contributes to the 
occurrence of adverse drug effects, drug-drug interactions, prolonged hospitalization, and increased health care costs [4]. Specifically, in SOTRs, this overuse contributes to the development of infections by multidrug-resistant (MDR) Gram-negative pathogens. In several studies performed among solid organ transplant recipients in Western countries, multidrug resistance was frequently encountered in the setting of Gram-negative bloodstream infections [5-10]. Of note, a study performed by Linares et al. in Spain reported the detection of extended-spectrum beta-lactamases in $54 \%$ of the Escherichia coli bacteremia episodes, while Johnson et al. detected the presence of multidrug resistance in $43 \%$ of the Pseudomonas aeruginosa bloodstream infections reported in a large US transplant center [5,9]. Third, limited data exist about the feasibility and applicability of antimicrobial stewardship (AMS) programs for SOTRs, since many established AMS programs are not inclusive of SOTRs and most studies of antimicrobial stewardship specifically exclude SOTRs. In this review, we discuss the above factors which contribute to the severity of lung infections in SOTRs.

\section{Results}

\subsection{Etiologic Diagnosis of Lung Infections in Solid Organ Transplant Recipients}

Conventional microbiology, which includes classical culture methods, antigen detection methods, serological methods, nucleic acid amplification methods, matrix-assisted laser desorption ionization-time of flight (MALDI-TOF) tests, and other diagnostic tools, provides relevant information for medical practice, allowing the identification and quantification of organisms in clinical samples and increasing the appropriateness of antimicrobial treatments [11].

Despite its undoubted clinical relevance, the performance of conventional microbiology is still suboptimal in many circumstances, especially in the setting of SOTRs, where the rapid and accurate identification of the causative pathogens of respiratory infections is critical for appropriate therapeutic management [3]. The most significant pitfalls of conventional microbiology are described below.

First, conventional microbiology's diagnostic capacity is restricted only to known or culturable pathogens. The wide range of potential opportunistic and non-opportunistic pathogens causing lung infections in SOTRs makes direct pathogen identification challenging [12]. However, most diagnostics today still focus on pathogen detection as the reference diagnostic approach. Even recently implemented microbiological diagnostics, such as MALDI-TOF and nucleic acid amplification tests, rely on pathogen detection. The clinical drawbacks of diagnostic approaches limited to known or culturable agents were well depicted by the events of 2009, when existing molecular assays failed to effectively detect a novel pandemic influenza virus.

Second, current diagnostics have suboptimal sensitivity and specificity. For example, Candida infections are frequently encountered among SOTRs, as shown by recent investigations among a high-volume US transplant center [13]. Unfortunately, Candida blood culture sensitivity is well known to be $<60 \%$, making the diagnosis of Candida invasive infections troublesome [14].

Third, while detecting pathogens, current tests are unable to discriminate between pathogens causing active disease and pathogens colonizing asymptomatic carriers. This is particularly relevant in the setting of cystic fibrosis lung transplant recipients. Both in the pretransplant and post-transplant periods, different microbial populations are detected in the airways of cystic fibrosis patients $[15,16]$. In the case of an acute respiratory infection, the identification of the causative pathogen among the many different organisms retrieved from respiratory cultures is extremely challenging [17].

Fourth, some SOTRs suffer from lung infections due to multiple simultaneous pathogens (such as concomitant influenza and fungal/bacterial pneumonia), where the detection of a single pathogen still omits critical information related to patient care.

Fifth, current diagnostic methods are limited by a prolonged wait for available results, which range from days to weeks, as in the case of mycobacterial cultures. The long turn-around times of nontuberculous mycobacterial cultures are prohibitive for critically ill solid organ transplant recipients, especially in the post-transplant period [18]. Long turn-around times still affect recently introduced 
diagnostic tests, such as MALDI-TOF. Specifically, while MALDI-TOF allows a more rapid identification of pathogens than biochemical tests, MALDI-TOF can be applied only to pure culture on solid media and not to unprocessed clinical samples. In other words, MALDI-TOF does not eliminate the time needed to obtain a pure culture, which is an important limiting step, especially in the setting of fastidious organisms. Furthermore, while detecting a wide range of bacteria, MALDI-TOF may not be conclusive for less common organisms, such as molds, which play a substantial role as a cause of lung infections in SOTRs. Based on these considerations, MALDI-TOF does not eliminate the need for fungal cultures and their prolonged time for results [19].

Histology, specifically transbronchial biopsies, also have several limitations: they are invasive, expensive, subject to sampling error and interobserver variability, and they may cause morbidity.

Therefore, based on the limitations of microbiology and histology, new diagnostic methods are strongly needed, as recognized by several researchers and international societies, such as the Antibacterial Resistance Leadership Group [3,20].

Preliminary studies performed among nontransplant populations showed the potential role of evaluating the host response to respiratory infections. Since immune response is largely conserved for a given pathogen class (e.g., bacteria, viruses, fungi, and protozoa), class-specific host gene response signatures can be identified. Transcriptome signatures are a powerful diagnostic tool in the setting of respiratory infections, as shown by several researchers [21-23]. Specifically, Suarez et al. identified a 10-gene classifier to discriminate bacterial and viral lung infections; this classifier was characterized by high sensitivity and specificity ( $95 \%$ and $92 \%$, respectively). Bhattacharya et al. developed an 11-gene signature that discriminated bacterial and nonbacterial lung infections with good diagnostic accuracy (sensitivity of $90 \%$ and specificity of $83 \%$ ). Tsalik et al. designed three separate classifiers in order to differentiate bacterial respiratory infections, viral respiratory infections, and noninfectious conditions. When pooled together, the classifiers designed by Tsalik et al. showed an overall diagnostic accuracy close to $90 \%$. SOTRs would benefit the most from host gene diagnostics, since respiratory infections are among the leading causes of morbidity and mortality in the post-transplant period and SOTRs are exposed to the risk of antibacterial overuse. Discriminating between bacterial and viral infections by the use of transcriptome classifiers such as the ones proposed by Tsalik et al. would reduce inappropriate antibacterial treatments and would hopefully limit the spread of antimicrobial resistance. Further studies are needed to assess the diagnostic validity of transcriptome classifiers among immunocompromised patients, such as SOTRs.

Finally, despite the abundance of scientific reports describing lung infections in SOTRs, few studies have attempted to evaluate the etiologic distribution of lung infections in this population (Table 1) [24-41]. 
Table 1. Main studies addressing the etiology of lung infections in solid organ transplant recipients.

\begin{tabular}{|c|c|c|c|c|c|c|c|c|c|c|c|}
\hline $\begin{array}{c}\text { First Author } \\
\text { and Publication } \\
\text { Year }\end{array}$ & $\begin{array}{c}\text { Study } \\
\text { Population }\end{array}$ & $\begin{array}{l}\text { Study Population } \\
\text { Details }\end{array}$ & Study Design & $\begin{array}{l}\text { Study } \\
\text { Period }\end{array}$ & $\begin{array}{l}\text { Lung Infections } \\
\text { Evaluated }\end{array}$ & $\begin{array}{l}\text { Prevalence } \\
\text { of Lung } \\
\text { Infections }\end{array}$ & $\begin{array}{l}\text { Diagnostic Tests } \\
\text { Implemented }\end{array}$ & $\begin{array}{l}\text { Patients with an } \\
\text { Etiological Diagnosis } \\
\text { among Patients with } \\
\text { Lung Infections }\end{array}$ & $\begin{array}{l}\text { Most Frequently } \\
\text { Identified Pathogens }\end{array}$ & $\begin{array}{l}\text { Analytical } \\
\text { Methods Used } \\
\text { for Etiology } \\
\text { Attribution }\end{array}$ & Reference \\
\hline Golfieri R, 2000 & $\begin{array}{l}\text { Liver transplant } \\
\quad \text { recipients } \\
(\mathrm{n}=300)\end{array}$ & $\begin{array}{c}\text { Consecutive } \\
\text { transplant recipients }\end{array}$ & $\begin{array}{l}\text { Single-center, } \\
\text { observational } \\
\text { retrospective } \\
\text { cohort study } \\
\end{array}$ & 1986-1997 & $\begin{array}{c}\text { Bacterial, } \\
\text { mycobacterial, } \\
\text { viral, and fungal } \\
\text { lung infections }\end{array}$ & $\begin{array}{l}41 / 300 \\
(13.7 \%)\end{array}$ & Respiratory cultures & $\mathrm{NA}$ & $\begin{array}{l}\text { Pseudomonas aeruginosa, } \\
\text { CMV, Candida spp. }\end{array}$ & Expert review & [24] \\
\hline Rao KH, 2002 & $\begin{array}{c}\text { Kidney } \\
\text { transplant } \\
\text { recipients } \\
(\mathrm{n}=40) \\
\end{array}$ & $\begin{array}{c}\text { Consecutive } \\
\text { transplant recipients }\end{array}$ & $\begin{array}{l}\text { Single-center, } \\
\text { observational } \\
\text { retrospective } \\
\text { cohort study }\end{array}$ & 1998-2000 & $\begin{array}{c}\text { Bacterial, } \\
\text { mycobacterial, } \\
\text { and fungal lung } \\
\text { infections }\end{array}$ & $\mathrm{NA}$ & $\begin{array}{c}\text { Respiratory cultures, } \\
\text { histology }\end{array}$ & $\mathrm{NA}$ & $\begin{array}{l}\text { Aspergillus spp., Candida } \\
\text { spp., Nocardia spp. }\end{array}$ & Expert review & [25] \\
\hline Loinaz C, 2003 & $\begin{array}{c}\text { Intestinal and } \\
\text { multivisceral } \\
\text { transplant } \\
\text { recipients } \\
(\mathrm{n}=124)\end{array}$ & $\begin{array}{l}\text { Consecutive } \\
\text { transplant recipients }\end{array}$ & $\begin{array}{l}\text { Single-center, } \\
\text { observational } \\
\text { retrospective } \\
\text { cohort study }\end{array}$ & 1994-2001 & $\begin{array}{l}\text { Bacterial lung } \\
\text { infections }\end{array}$ & $\begin{array}{l}38 / 124 \\
(30.6 \%)\end{array}$ & Respiratory cultures & NA & Pseudomonas aeruginosa & Expert review & [26] \\
\hline $\begin{array}{l}\text { Bonvillain RW, } \\
\quad 2007\end{array}$ & $\begin{array}{l}\text { Lung transplant } \\
\quad \text { recipients } \\
(\mathrm{n}=120)\end{array}$ & $\begin{array}{l}\text { Nonconsecutive } \\
\text { bilateral lung } \\
\text { transplant recipients }\end{array}$ & $\begin{array}{l}\text { Single-center, } \\
\text { observational } \\
\text { retrospective } \\
\text { cohort study } \\
\end{array}$ & 1990-2005 & $\begin{array}{c}\text { Bacterial, } \\
\text { mycobacterial, } \\
\text { viral, and fungal } \\
\text { lung infections }\end{array}$ & NA & $\begin{array}{l}\text { Respiratory cultures, } \\
\text { blood cultures }\end{array}$ & NA & $\begin{array}{l}\text { Pseudomonas aeruginosa, } \\
\text { Staphylococcus aureus, } \\
\text { Aspergillus spp. }\end{array}$ & Expert review & [27] \\
\hline Husain S, 2007 & $\begin{array}{l}\text { Lung transplant } \\
\quad \text { recipients } \\
(\mathrm{n}=116)\end{array}$ & $\begin{array}{c}\text { Consecutive lung } \\
\text { transplant recipients } \\
\text { undergoing } \\
\text { bronchoscopy } \\
\end{array}$ & $\begin{array}{c}\text { Single-center, } \\
\text { observational } \\
\text { prospective } \\
\text { cohort study }\end{array}$ & 2003-2005 & $\begin{array}{l}\text { Aspergillus } \\
\text { infections }\end{array}$ & $\begin{array}{l}6 / 116 \\
(5.2 \%)\end{array}$ & Respiratory cultures & $\begin{array}{c}6 / 6 \\
(100 \%)\end{array}$ & Aspergillus spp. & Expert review & [28] \\
\hline Campos S, 2008 & $\begin{array}{l}\text { Lung transplant } \\
\text { recipients } \\
\quad(\mathrm{n}=49)\end{array}$ & $\begin{array}{c}\text { Consecutive } \\
\text { transplant recipients }\end{array}$ & $\begin{array}{l}\text { Single-center, } \\
\text { observational } \\
\text { retrospective } \\
\text { cohort study }\end{array}$ & 2003-2007 & $\begin{array}{l}\text { Bacterial and } \\
\text { fungal lung } \\
\text { infections }\end{array}$ & NA & $\begin{array}{l}\text { Respiratory cultures, } \\
\text { blood cultures, and } \\
\text { histology }\end{array}$ & NA & $\begin{array}{l}\text { Pseudomonas aeruginosa, } \\
\text { Staphylococcus aureus, } \\
\text { Aspergillus spp. }\end{array}$ & Expert review & [29] \\
\hline Mota PC, 2009 & $\begin{array}{l}\text { Kidney } \\
\text { transplant } \\
\text { recipients } \\
(\mathrm{n}=36)\end{array}$ & $\begin{array}{l}\text { Consecutive kidney } \\
\text { transplant recipients } \\
\text { presenting with } \\
\text { respiratory } \\
\text { symptoms }\end{array}$ & $\begin{array}{l}\text { Single-center, } \\
\text { observational } \\
\text { retrospective } \\
\text { cohort study }\end{array}$ & NA & $\begin{array}{l}\text { Bacterial and } \\
\text { fungal lung } \\
\text { infections }\end{array}$ & $\begin{array}{l}36 / 36 \\
(100 \%)\end{array}$ & $\begin{array}{l}\text { Respiratory cultures } \\
\text { and blood cultures }\end{array}$ & $\begin{array}{c}7 / 36 \\
(19.4 \%)\end{array}$ & $\begin{array}{l}\text { Streptococcus pneumoniae, } \\
\text { Hemophilus influenzae, } \\
\text { Staphylococcus aureus }\end{array}$ & Expert review & [30] \\
\hline Kupeli E, 2011 & $\begin{array}{l}\text { Kidney } \\
\text { transplant } \\
\text { recipients } \\
(\mathrm{n}=136)\end{array}$ & $\begin{array}{l}\text { Consecutive kidney } \\
\text { transplant recipients }\end{array}$ & $\begin{array}{l}\text { Single-center, } \\
\text { observational } \\
\text { retrospective } \\
\text { cohort study }\end{array}$ & 2007-2010 & $\begin{array}{c}\text { Bacterial, } \\
\text { mycobacterial, } \\
\text { and fungal lung } \\
\text { infections }\end{array}$ & $\begin{array}{l}12 / 136 \\
(8.8 \%)\end{array}$ & Respiratory cultures & $\begin{array}{c}5 / 12 \\
(41.7 \%)\end{array}$ & $\begin{array}{l}\text { Streptococcus pneumoniae, } \\
\text { Acinetobacter baumanii, } \\
\text { Mycobacterium tuberculosis }\end{array}$ & Expert review & [31] \\
\hline Qin J, 2012 & $\begin{array}{l}\text { Liver transplant } \\
\quad \text { recipients } \\
(\mathrm{n}=2550)\end{array}$ & $\begin{array}{l}\text { Consecutive liver } \\
\text { transplant recipients }\end{array}$ & $\begin{array}{l}\text { Single-center, } \\
\text { observational } \\
\text { retrospective } \\
\text { cohort study }\end{array}$ & 2000-2011 & $\begin{array}{c}\text { Bacterial, } \\
\text { mycobacterial, } \\
\text { viral, and fungal } \\
\text { lung infections }\end{array}$ & $\begin{array}{l}453 / 2550 \\
(17.8 \%)\end{array}$ & $\begin{array}{l}\text { Respiratory cultures, } \\
\text { blood cultures, } \\
\text { histology, CMV } \\
\text { antigenemia }\end{array}$ & NA & $\begin{array}{l}\text { Staphylococcus aureus, } \\
\text { CMV, Pseudomonas } \\
\text { aeruginosa }\end{array}$ & Expert review & [32] \\
\hline
\end{tabular}


Table 1. Cont.

\begin{tabular}{|c|c|c|c|c|c|c|c|c|c|c|c|}
\hline $\begin{array}{c}\text { First Author } \\
\text { and Publication } \\
\text { Year }\end{array}$ & $\begin{array}{c}\text { Study } \\
\text { Population }\end{array}$ & $\begin{array}{l}\text { Study Population } \\
\text { Details }\end{array}$ & Study Design & $\begin{array}{l}\text { Study } \\
\text { Period }\end{array}$ & $\begin{array}{l}\text { Lung Infections } \\
\text { Evaluated }\end{array}$ & $\begin{array}{l}\text { Prevalence } \\
\text { of Lung } \\
\text { Infections }\end{array}$ & $\begin{array}{l}\text { Diagnostic Tests } \\
\text { Implemented }\end{array}$ & $\begin{array}{l}\text { Patients with an } \\
\text { Etiological Diagnosis } \\
\text { among Patients with } \\
\text { Lung Infections }\end{array}$ & $\begin{array}{l}\text { Most Frequently } \\
\text { Identified Pathogens }\end{array}$ & $\begin{array}{l}\text { Analytical } \\
\text { Methods Used } \\
\text { for Etiology } \\
\text { Attribution }\end{array}$ & Reference \\
\hline $\begin{array}{l}\text { Eyuboglu FO, } \\
2013\end{array}$ & $\begin{array}{l}\text { Liver, heart, and } \\
\text { kidney } \\
\text { transplant } \\
\text { recipients } \\
(\mathrm{n}=998) \\
\end{array}$ & $\begin{array}{l}\text { HIV-Ab negative } \\
\text { consecutive } \\
\text { transplant recipients }\end{array}$ & $\begin{array}{l}\text { Single-center, } \\
\text { observational } \\
\text { retrospective } \\
\text { cohort study }\end{array}$ & 2000-2012 & $\begin{array}{c}\text { Bacterial, } \\
\text { mycobacterial, } \\
\text { and fungal lung } \\
\text { infections }\end{array}$ & $\begin{array}{l}73 / 998 \\
(7.3 \%)\end{array}$ & Respiratory cultures & $\begin{array}{c}32 / 73 \\
(43.8 \%)\end{array}$ & $\begin{array}{l}\text { Mycobacterium tuberculosis, } \\
\text { Staphylococcus aureus, } \\
\text { Moraxella catharralis }\end{array}$ & Expert review & [33] \\
\hline Kim SY, 2013 & $\begin{array}{l}\text { Lung transplant } \\
\text { recipients } \\
(\mathrm{n}=48)\end{array}$ & $\begin{array}{c}\text { Consecutive lung } \\
\text { transplant recipients } \\
\text { presenting with } \\
\text { respiratory } \\
\text { symptoms } \\
\end{array}$ & $\begin{array}{l}\text { Single-center, } \\
\text { observational } \\
\text { retrospective } \\
\text { cohort study }\end{array}$ & NA & $\begin{array}{c}\text { Bacterial, } \\
\text { mycobacterial, } \\
\text { viral, and fungal } \\
\text { lung infections }\end{array}$ & $\begin{array}{c}48 / 48 \\
(100 \%)\end{array}$ & NA & $\begin{array}{c}42 / 48 \\
(87.5 \%)\end{array}$ & $\begin{array}{l}\text { Acinetobacter baumanii, } \\
\text { Pseudomonas aeruginosa, } \\
\text { Staphylococcus aureus }\end{array}$ & Expert review & [34] \\
\hline $\begin{array}{l}\text { Hekimoglu K, } \\
2015\end{array}$ & $\begin{array}{l}\text { Liver transplant } \\
\text { recipients }(\mathrm{n}=188)\end{array}$ & $\begin{array}{l}\text { Consecutive adult } \\
\text { liver transplant } \\
\text { recipients presenting } \\
\text { with respiratory } \\
\text { complications }\end{array}$ & $\begin{array}{l}\text { Single-center, } \\
\text { observational } \\
\text { retrospective } \\
\text { cohort study }\end{array}$ & 2002-2013 & $\begin{array}{c}\text { Bacterial, } \\
\text { mycobacterial, } \\
\text { viral, and fungal } \\
\text { lung infections }\end{array}$ & $\begin{array}{c}34 / 188 \\
(18.1 \%)\end{array}$ & NA & $\begin{array}{c}34 / 34 \\
(100 \%)\end{array}$ & $\begin{array}{l}\text { Streptococcus pneumoniae, } \\
\text { Klebsiella pneumoniae, } \\
\text { Candida spp. }\end{array}$ & Expert review & [35] \\
\hline Li JJ, 2015 & $\begin{array}{l}\text { Kidney } \\
\text { transplant } \\
\text { recipients } \\
(\mathrm{n}=52)\end{array}$ & $\begin{array}{l}\text { Consecutive kidney } \\
\text { transplant recipients } \\
\text { with respiratory } \\
\text { infections }\end{array}$ & $\begin{array}{l}\text { Single-center, } \\
\text { observational } \\
\text { retrospective } \\
\text { cohort study }\end{array}$ & 2008-2013 & $\begin{array}{c}\text { Bacterial, } \\
\text { mycobacterial, } \\
\text { viral, and fungal } \\
\text { lung infections }\end{array}$ & $\begin{array}{c}52 / 52 \\
(100 \%)\end{array}$ & $\begin{array}{c}\text { Respiratory cultures, } \\
\text { blood cultures, } \\
\text { NAAT, Aspergillus } \\
\text { Ag, 1-3 B dextran } \\
\text { antigen }\end{array}$ & $\begin{array}{c}40 / 52 \\
(46.9 \%)\end{array}$ & Gram-negative bacteria & Expert review & [36] \\
\hline Shah SK, 2016 & $\begin{array}{l}\text { Lung transplant } \\
\quad \text { recipients } \\
(\mathrm{n}=202)\end{array}$ & $\begin{array}{l}\text { Consecutive lung } \\
\text { transplant recipients }\end{array}$ & $\begin{array}{l}\text { Single-center, } \\
\text { observational } \\
\text { retrospective } \\
\text { cohort study } \\
\end{array}$ & 1990-2005 & $\begin{array}{l}\text { Mycobacterial } \\
\text { lung infections }\end{array}$ & $\begin{array}{c}30 / 202 \\
(14.8 \%)\end{array}$ & $\begin{array}{l}\text { BAL, sputum, and } \\
\text { blood mycobacterial } \\
\text { cultures }\end{array}$ & NA & $\begin{array}{l}\text { Mycobacterium abscessus, } \\
\text { Mycobacterium avium, } \\
\text { Mycobacterium gordonae. }\end{array}$ & Expert review & [37] \\
\hline $\begin{array}{l}\text { Aspelund AS, } \\
\quad 2018\end{array}$ & $\begin{array}{l}\text { Lung transplant } \\
\text { recipients } \\
(\mathrm{n}=126)\end{array}$ & $\begin{array}{l}\text { Consecutive adult } \\
\text { lung transplant } \\
\text { recipients }\end{array}$ & $\begin{array}{l}\text { Multicenter, } \\
\text { observational } \\
\text { prospective } \\
\text { cohort study }\end{array}$ & 2012-2014 & $\begin{array}{c}\text { Bacterial, } \\
\text { mycobacterial, } \\
\text { viral, and fungal } \\
\text { lung infections }\end{array}$ & $\begin{array}{l}57 / 126 \\
(45.2 \%)\end{array}$ & $\begin{array}{l}\text { Respiratory cultures, } \\
\text { NAAT, histology }\end{array}$ & $\begin{array}{c}57 / 57 \\
(100 \%)\end{array}$ & $\begin{array}{c}\text { Candida spp., } \text { Pseudomonas } \\
\text { aeruginosa, Staphylococcus } \\
\text { aureus }\end{array}$ & Expert review & [38] \\
\hline $\begin{array}{l}\text { Magnusson J, } \\
\quad 2018\end{array}$ & $\begin{array}{l}\text { Lung transplant } \\
\text { recipients } \\
(\mathrm{n}=98)\end{array}$ & $\begin{array}{l}\text { Consecutive adult } \\
\text { lung transplant } \\
\text { recipients }\end{array}$ & $\begin{array}{l}\text { Single-center, } \\
\text { observational } \\
\text { prospective } \\
\text { cohort study }\end{array}$ & 2009-2012 & Viral infections & $\begin{array}{c}51 / 98 \\
(52.0 \%)\end{array}$ & NAAT & $\begin{array}{c}51 / 51 \\
(100 \%)\end{array}$ & $\begin{array}{l}\text { Rhinovirus, coronavirus, } \\
\text { respiratory syncytial virus }\end{array}$ & Expert review & [39] \\
\hline $\begin{array}{l}\text { Onyearugbulem } \\
\text { C, } 2018\end{array}$ & $\begin{array}{l}\text { Lung transplant } \\
\quad \text { recipients } \\
\quad(\mathrm{n}=98)\end{array}$ & $\begin{array}{c}\text { Consecutive } \\
\text { pediatric lung } \\
\text { transplant recipients }\end{array}$ & $\begin{array}{l}\text { Single-center, } \\
\text { observational } \\
\text { retrospective } \\
\text { cohort study } \\
\end{array}$ & 2009-2016 & $\begin{array}{c}\text { Bacterial, } \\
\text { mycobacterial, } \\
\text { viral, and fungal } \\
\text { lung infections }\end{array}$ & $\begin{array}{l}6 / 98 \\
(6.1 \%)\end{array}$ & $\begin{array}{l}\text { Respiratory cultures, } \\
\text { blood cultures, } \\
\text { NAAT }\end{array}$ & $\begin{array}{c}6 / 6 \\
(100 \%)\end{array}$ & $\begin{array}{l}\text { Respiratory viruses, } \\
\text { Mycobacterium abscessus }\end{array}$ & Expert review & [40] \\
\hline $\begin{array}{l}\text { Tachibana K, } \\
2018\end{array}$ & $\begin{array}{l}\text { Lung transplant } \\
\text { recipients } \\
(\mathrm{n}=240)\end{array}$ & $\begin{array}{l}\text { Consecutive lung } \\
\text { transplant recipients }\end{array}$ & $\begin{array}{l}\text { Multicenter, } \\
\text { observational } \\
\text { retrospective } \\
\text { cohort study }\end{array}$ & 2000-2014 & $\begin{array}{l}\text { Mycobacterial } \\
\text { and fungal } \\
\text { infections }\end{array}$ & NA & $\begin{array}{l}\text { Respiratory cultures, } \\
\text { Aspergillus antigen } \\
\text { and antibodies }\end{array}$ & $12 / \mathrm{NA}$ & $\begin{array}{l}\text { Mycobacterium avium } \\
\text { complex, Mycobacterium } \\
\text { fortuitum, Mycobacterium } \\
\text { kansasii, Mycobacterium } \\
\text { gordonae, Mycobacterium } \\
\text { abscessus, Aspergillus spp. }\end{array}$ & Expert review & [41] \\
\hline
\end{tabular}


A clear understanding of the etiologic distribution of lung infections in SOTRs is hampered by several factors. First, lung infection studies in SOTRs generally lack a clinical case definition that is both sensitive and specific, which leads to missing a substantial proportion of SOTRs with lung infections or including a significant number of SOTRs without lung infections in etiologic studies. Clinical case definitions are widely used only for nontuberculous mycobacterial and fungal lung infections in SOTRs $[42,43]$. Second, the accuracy of etiologic studies is limited by rarely testing the tissue where the infection occurs, that is, the lung. The etiology of lung infections in SOTRs is frequently inferred from tests performed on samples contiguous to the pulmonary tissue or from tests performed on body fluids that are a proxy for the lung tissue, such as sputum, nasopharyngeal secretions, blood, or urine. Third, the etiology of lung infections in SOTRs is dynamic and reflects changes in immunosuppressive treatments, antimicrobial prophylaxis, vaccination programs, surgical procedures, and laboratory diagnostic tests. The evolution over time of the etiologic distribution of lung infections in SOTRs poses a restraint on the applicability of etiologic studies performed in the past. Similarly, the selective geographical distribution of certain respiratory pathogens, such as endemic fungi, Mycobacterium tuberculosis, or nontuberculous mycobacteria, constitutes an obstacle to the generalizability of etiologic studies. Fourth, the pathophysiology behind single-pathogen and multi-pathogen lung infections in SOTRs has not yet been fully described, making the interpretation of diagnostic tests difficult if not misleading [44]. Fifth, fatal cases are usually under-represented in etiologic studies. This may be due to the fact that (i) the sickest SOTRs often die soon after presentation; (ii) in cases of severe lung infections, resuscitation and medical procedures have priority over research studies; (iii) sick patients may not be candidates for invasive procedures (e.g., a severe lung infection in a SOTR might make a bronchoscopy impractical due to the oxygen requirement of the patient); and (iv) autopsy studies are rarely performed. The under-representation of fatal cases in lung infection studies leads to uncertainty about the causes of lung infection mortality among SOTRs. Sixth, lung infection etiologic studies in SOTRs require analytical approaches that can integrate the results of multiple tests on multiple samples and that can account for the imperfect sensitivity and specificity of each diagnostic test. The scientific literature is rich in case-only studies, where the etiologic distribution of infections is derived from latent class analysis or expert review; similarly, logistic regression and attributable fraction analysis have been applied to case-control etiologic studies. Each of these analytical methods has significant limitations and none integrate multiple test results [45].

The limitations of etiologic research in the setting of lung infections in SOTRs are similar to the limitations perceived in pneumonia etiologic studies. A substantial attempt to overcome the limitations of pneumonia etiologic studies was promoted in 2007 by the Bill \& Melinda Gates Foundation and resulted in the international "Pneumonia Etiology Research for Child Health" (PERCH) study [46,47]. PERCH aimed to characterize the etiology of severe pneumonia in children in Sub-Saharan Africa and Asia. To achieve this goal, PERCH enrolled more than 4000 pneumonia cases and more than 5000 controls and is likely the most comprehensive etiologic study of pneumonia. Of note, PERCH not only enrolled a large study population but also developed a Bayesian integrated approach that incorporated evidence from multiple samples from cases and controls and that accounted for the imperfect diagnostic accuracy of the tests used [46,47]. The application of novel analytical methods, such as the PERCH integrated analysis, could be a key component of future studies assessing the etiology of lung infections in SOTRs.

\subsection{Management of Lung Infections in Solid Organ Transplant Recipients in the Era of Increased Antimicrobial Resistance}

Bacterial infections have always been a leading cause of morbidity and mortality among SOTRs, threatening the success of transplantation [2]. In the last decades, the severity of bacterial infections in SOTRs increased due to the emergence of MDR Gram-negative organisms, defined as bacteria non-susceptible to $\geq 1$ agent in three or more antimicrobial categories [48-51]. Frequent antibiotic exposure, microbiome alterations, recurrent hospitalizations, and hepatic failure are major risk factors 
associated with MDR Gram-negative infections in the pretransplant period. Renal replacement therapy, prolonged mechanical ventilation, and tracheal intubation in the post-transplant period increase the susceptibility of SOTRs to MDR Gram-negative infections [48].

The identification of MDR Gram-negative organisms in SOTRs poses several questions. Once MDR Gram-negative organisms are identified in respiratory samples by microbiological tests, their role in the host still remains to be ascertained. Specifically, MDR Gram-negative organisms could either colonize the airways or they could cause respiratory infections. Airway colonization is characterized by the presence of MDR Gram-negative organisms in the respiratory secretions, detected by microbiological tests in the absence of symptoms, as well as radiologic and endobronchial changes [52]. While MDR Gram-negative organism airway colonization does not warrant treatment, it is a very important risk factor for invasive respiratory infections [53]. Furthermore, in the setting of lung transplantation, MDR Gram-negative organism airway colonization is a known independent determinant of chronic organ dysfunction [54]. Transient bacterial airway colonization can significantly increase bronchoalveolar lavage (BAL) neutrophils and other indicators of lung inflammation [55]. Botha et al. examined 155 consecutive lung transplants and reported that de novo allograft colonization with P. aeruginosa was strongly associated with developing bronchiolitis obliterans syndrome (BOS) within 2 years of transplantation [56]. Vos and collaborators reported that persistent $P$. aeruginosa colonization was an even greater risk for BOS than de novo colonization [57,58]. Additionally, Gottlieb et al. found that persistent allograft colonization with P. aeruginosa in recipients with cystic fibrosis significantly increased the prevalence of BOS [59].

Among MDR Gram-negative bacteria, P. aeruginosa, Acinetobacter baumanii, and carbapenemresistant Enterobacteriaceae are the main causative agents of respiratory infections in SOTRs. Therapeutic options for the treatment of MDR P. aeruginosa, A. baumanii, and carbapenem-resistant Enterobacteriaceae are limited.

MDR P. aeruginosa can be responsible for early post-transplant respiratory infections in SOTRs, especially among lung transplant recipients $[6,7,60,61]$. The higher risk of MDR P. aeruginosa respiratory infections among lung transplant recipients compared with other solid organ transplants may be due to the persistent colonization of the upper airways and paranasal sinuses in the pre- and post-transplant periods. In this regard, Walter et al. found that P. aeruginosa-free lungs transplanted in cystic fibrosis patients became infected with $P$. aeruginosa clones that were identical in genotype to the isolates from the explanted cystic fibrosis lungs, highlighting that colonization occurred from the patients' upper airways and sino-nasal space [62].

In the pipeline of new antibiotics, ceftolozane/tazobactam has a major role in the treatment of MDR P. aeruginosa infections. Ceftolozane/tazobactam is stable against overexpression of Pseudomonas-derived cephalosporinase or efflux pumps as well as against extended-spectrum beta-lactamases, conserving activity against most pan- $\beta$-lactam-resistant clinical strains [63]. On the contrary, ceftolozane/tazobactam is susceptible to hydrolysis by carbapenemase enzymes, such as metallo- $\beta$-lactamases (MBLs); in such cases, old antibiotics, such as aminoglycosides or colistin, are often the only possible therapeutic options. The use of aztreonam in combination with avibactam for MBLs-producing P. aeruginosa might be considered in selected cases of proven susceptibility; however, the production of MBLs in Pseudomonas is often associated with other mechanisms of beta-lactam resistance, making this combination not active [64].

Due to its nephrotoxicity, colistin is recommended only in situations where ceftolozane/tazobactam cannot be used [48]. Overall, screening for carbapenemases production as well as susceptibility testing for new antibiotics is highly warranted in order to define the most appropriate treatment for MDR $P$. aeruginosa infections in SOTRs. Finally, recent retrospective studies and meta-analyses did not show any survival benefit in the use of combination regimens compared to monotherapy for the treatment of MDR P. aeruginosa [65-68].

Studies investigating the distribution, drug resistance, and clinical characteristics of $A$. baumannii infections in SOTRs reported that more than $80 \%$ of such infections were due to MDR or extensively 
drug resistant (XDR) strains, with almost all of these isolates being resistant to carbapenems and an overall infection-related mortality up to $40 \%[69,70]$.

No new antibiotics are currently available for the treatment of MDR A. baumannii and clinicians should rely on combinations of old antimicrobials. Antibiotics for MDR A. baumannii include polymyxins, ampicillin/sulbactam, and tigecycline. Rifampicin, glycopeptides, or fosfomycin can be used in association with other active molecules, such as polymyxins. Susceptibility testing should always be performed in order to allow the choice of an appropriate therapy according to the specific isolate.

Colistin demonstrated its activity against MDR A. baumannii in several retrospective studies, despite a worrisome risk of selection of resistances when used in monotherapy [71-73]. In a study by Shields et al., treatment with a colistin/carbapenem regimen was an independent predictor of 28-day survival in SOTRs with XDR A. baumannii respiratory infections [74]. While in vitro synergism against $A$. baumannii was described for colistin and rifampin, no differences in mortality were found in patients with $A$. baumannii pneumonia treated with colistin and rifampin compared to patients treated with colistin monotherapy $[75,76]$. Furthermore, the use of rifampicin in SOTRs is limited by the pharmacological interactions of rifampin with several immunosuppressive drugs, including tacrolimus and cyclosporine. Sulbactam retains intrinsic activity against $A$. baumannii, and its association with ampicillin has been demonstrated to be effective against severe infections due to $A$. baumannii, including pneumonia [77]; however, mortality in this setting remains high and resistances to this combination are rising [78]. Tigecycline also retains in vitro activity against $A$. baumannii. Unfortunately, tigecycline use is not recommended in the setting of respiratory infections due to tigecycline pharmacokinetic characteristics. Tigecycline may be an option for the treatment of $A$. baumannii pneumonia only if the $\mathrm{MIC}$ is $\leq 1 \mathrm{mg} / \mathrm{L}$ and the isolate is resistant to other agents. In this event, high doses (loading dose of $200 \mathrm{mg}$ followed by $100 \mathrm{mg}$ every $12 \mathrm{~h}$ ) are preferable [79]. Eravacycline may represent a future option for the treatment of MDR A. baumannii in SOTRs.

SOTRs are at increased risk for carbapenem-resistant Enterobacteriaceae infections, especially carbapenem-resistant Klebsiella pneumoniae infections [80]. Giannella et al. described 20 carbapenem-resistant K. pneumoniae infections among 237 liver transplant recipients, with respiratory infections accounting for $15.0 \%$ of the carbapenem-resistant Enterobacteriaceae infections. Infections were more common among carbapenem-resistant K. pneumoniae-colonized patients than among non-colonized patients [81]. Similar results were reported by Bergamasco et al. [82].

Different new antibiotics have recently become available for carbapenem-resistant Enterobacteriaceae. However, the experience with these molecules in real-life settings is still scarce, as is the evidence of their superiority versus old schemes [83-85]. Data are even more scarce in the setting of SOTRs, as they are mainly limited to small series rather than large cohorts $[10,86-88]$. Ceftazidime/avibactam inhibits the activity of class A and D carbapenemases, including KPC and OXA 48, but it is not active against class B carbapenemases. Ceftazidime/avibactam is approved for hospital-acquired and ventilator-associated pneumonia, although recent studies recognized pneumonia as a risk factor for microbiologic failure and ceftazidime/avibactam resistance among patients with carbapenem-resistant Enterobacteriaceae infections [89]. Although there is no evidence to support recommending the use of ceftazidime/avibactam in association with other antimicrobials, combination treatment seems strongly reasonable given the recent report of resistances and the high mortality associated with infections due to carbapenem-resistant Enterobacteriaceae [89]. Other new antibiotics likely to have a role per se or within combination therapies in the treatment of carbapenem-resistant Enterobacteriaceae infections include cefiderocol, meropenem/vaborbactam, imipenem/relebactam, and plazomicin [90-92]. 


\subsection{Antimicrobial Stewardship Programs in Solid Organ Transplant Recipients in the Era of Increased Antimicrobal Resistance}

AMS programs are crucial to counteract antimicrobial resistance. As suggested by the US Centers for Disease Control and Prevention (CDC), AMS programs should work on key drivers for reducing inappropriate antimicrobial utilization. The following interventions were proposed by the US CDC as key drivers: (i) promoting a culture of optimal antibiotic use within a facility, (ii) timely and appropriate initiation of antibiotics, (iii) appropriate administration and de-escalation, and (iv) favoring AMS program data monitoring and transparency and creating a stewardship infrastructure [93].

Despite the US CDC recommendations, AMS programs are still uncommon among immunocompromised patients, and SOTRs specifically. A large survey conducted in 2015 in 71 US transplant centers described the presence of an AMS program in 62 of the 71 centers surveyed $(87 \%)$. Of the 62 AMS programs, the proportion performing stewardship activities that were inclusive of adult and pediatric SOTRs was $46(74 \%)$ and $29(47 \%)$, respectively. This survey also found that commonly developed institutional guidelines for SOTRs were focused on management of invasive fungal infections, CMV infection, and fever and neutropenia [94]. Institutional guidelines did not provide guidance for the use of antibacterials in SOTRs. Furthermore, concordance of anti-infective treatment prescriptions with available recommendations and guidelines was suboptimal among SOTRs. One of the largest Canadian transplant centers conducted real-time audits on all antimicrobial therapies in transplant patients in 2013 and assessed each regimen against stewardship principles established by the Centers for Disease Prevention and Control, supplemented by applicable transplant-specific infection guidelines. Fifty-eight percent of the transplant recipients audited (103/176) received at least one antimicrobial, of which $30 \%$ were discordant with stewardship principles. The most common stewardship-discordant categories were lack of de-escalation (34.4\%), empiric antimicrobial spectrum being too broad $(12.5 \%)$, and therapy duration being too long $(21.8 \%)$. All these prescription patterns are associated with an increased risk of antimicrobial resistance development. Infectious disease consultation was associated with more stewardship-concordant prescriptions $(p=0.03)$ [4].

Preliminary efforts of AMS interventions in immunocompromised patients have been associated with a positive effect on the outcome of these critically ill patients $[95,96]$. A large single-center study conducted on SOTRs at Toronto General Hospital demonstrated that formal consultation with an infectious diseases specialist was associated with a significant reduction in 28-day mortality and lower readmission rates, suggesting a clinical benefit from a hospital policy of routine infectious disease specialist consultation in SOT centers [95]. Formal studies assessing the benefits associated with the implementation of AMS programs among SOTRs are urgently needed, as requested in 2013 by some of the leading US transplant centers [97].

\section{Discussion}

This review highlights the many challenges posed by the management of respiratory infections among SOTRs and paves the way for new research studies. Specifically, this review identifies the intrinsic limitations of diagnostic tests, the imperfect knowledge of the etiologic distribution of respiratory infections among SOTRs, the increasing prevalence of MDR Gram-negative pathogens, and the lack of SOTR-dedicated antimicrobial stewardship programs as the main obstacles clinicians face when dealing with respiratory infections in SOTRs.

This review is not exhaustive of all the challenges associated with the diagnosis and management of respiratory infections in SOTRs. For example, while describing the emergence of antimicrobial resistance against bacteria, this review does not cover the issue of resistance among antivirals and antifungals. Similarly, this review does not address in detail opportunistic infections, as well as tuberculous and non-tuberculous mycobacterial respiratory infections. The review does not describe prophylaxis or infection control policies for the containment of respiratory infections among SOTRs.

Despite its limitations, this review calls for innovative epidemiology- and microbiology-based strategies in order to increase survival among solid organ transplant recipients experiencing respiratory 
infections. Specifically, this review prompts future studies to (i) explore new diagnostic tools, such as host gene expression and microbiome analysis, for identifying the etiologic agents of respiratory infections in SOTRs; (ii) develop accurate analytic methods for describing the etiologic distribution of respiratory infections in SOTRs; (iii) assess the clinical outcomes associated with the use of new antibacterials for respiratory infections in SOTRs; and (iv) evaluate the safety and cost-effectiveness of SOTR-dedicated antimicrobial stewardship programs.

\section{Materials and Methods}

An extensive search was conducted of the relevant literature, with a focus on literature published in the last 10 years (2000-2019). Key search concepts used were transplant, solid organ, and bacterial infections. Searches that combined the above search concepts using AND operators were executed using PubMed. The searches were last performed on 20 September 2019.

Author Contributions: Conceptualization, M.C., L.C.M., A.M.P., L.A., V.R., A.B., A.G., and F.B.; methodology, M.C.; formal analysis, M.C. and V.R.; writing-original draft preparation, M.C., L.C.M., A.M.P., L.A., and V.R.; writing-review and editing, M.C., A.B., A.G., F.B, and IFALT working group.; supervision, A.B., A.G., and F.B. All authors have read and agreed to the published version of the manuscript.

Funding: This research was funded by the Italian "Ministero dell'Istruzione, dell'Università e della Ricerca", grant number ARS01_00530.

Acknowledgments: We acknowledge the scientific contribution and support of the IFALT working group. Internal Medicine Department, Division of Infectious Diseases, Fondazione IRCCS Cà Granda Ospedale Maggiore Policlinico Milano (Milano, Italy): Laura Alagna, Marina Allegrini, Alessandra Bandera, Matteo Bolis, Manuela Carugati, Valentina Ferroni, Andrea Gori, Teresa Itri, Davide Mangioni, Debora Mondatore, Valeria Pastore, and Federica Portunato. Internal Medicine Department, Respiratory Unit and Adult Cystic Fibrosis Center, Fondazione IRCCS Cà Granda Ospedale Maggiore Policlinico Milano (Milano, Italy): Stefano Aliberti, Francesco Blasi, Letizia Corinna Morlacchi, Martina Oriano, Valeria Rossetti, Paolo Tarsia, and Leonardo Terranova. Thoracic Surgery and Lung Transplant Unit, Fondazione IRCCS Cà Granda Ospedale Maggiore Policlinico Milano (Milano, Italy): Rosaria Carrinola, Francesco Damarco, Paolo Mendogni, Mario Nosotti. Alessandro Palleschi, Ilaria Righi, Lorenzo Rosso, and Davide Tosi. Pathology Department, Fondazione IRCCS Cà Granda Ospedale Maggiore Policlinico Milano (Milano, Italy): Stefano Bogetto Ferrero. Department of Biomedical and Clinical Sciences, Università degli Studi di Milano (Milano, Italy): Mario Clerici, Claudio Fenizia, and Daria Trabattoni. Department of Oncology and Hemato-Oncology, Università degli Studi di Milano (Milano, Italy): Claudia Alteri and Carlo Federico Perno. Department of Clinical and Experimental Medicine, Università degli Studi di Sassari (Sassari, Italy): Giovanni Sotgiu. Genprobio srl: Marco Ventura and Claudio Pessina. Prossima Isola srl: Daniele Idini.

Conflicts of Interest: The authors declare no conflict of interest. The funder had no role in the design of the study; in the collection, analyses, or interpretation of data; in the writing of the manuscript; or in the decision to publish the results.

\section{Abbreviations}

$\begin{array}{ll}\text { AMS } & \text { Antimicrobial stewardship } \\ \text { BAL } & \text { Bronchoalveolar lavage } \\ \text { CMV } & \text { Cytomegalovirus } \\ \text { IFALT } & \text { Investigating respiratory FAilure in Lung Transplant patients (IFALT) } \\ \text { MBL } & \text { Metallo- } \beta \text {-lactamases } \\ \text { NAAT } & \text { Nucleic acid amplification test } \\ \text { SOTR } & \text { Solid organ transplant recipients }\end{array}$

\section{References}

1. Fishman, J.A. Infection in solid-organ transplant recipients. N. Engl. J. Med. 2007, 357, 2601-2614. [CrossRef] [PubMed]

2. Shao, M.; Wan, Q.; Xie, W.; Ye, Q. Bloodstream infections among solid organ transplant recipients: Epidemiology, microbiology, associated risk factors for morbility and mortality. Transplant. Rev. 2014, 28, 176-181. [CrossRef] [PubMed]

3. Holcomb, Z.E.; Tsalik, E.L.; Woods, C.W.; McClain, M.T. Host-based peripheral blood gene expression analysis for diagnosis of infectious diseases. J. Clin. Microbiol. 2017, 55, 360-368. [CrossRef] [PubMed] 
4. So, M.; Yang, D.Y.; Bell, C.; Humar, A.; Morris, A.; Husain, S. Solid organ transplant patients: Are there opportunities for antimicrobial stewardship? Clin. Transplant. 2016, 30, 659-668. [CrossRef]

5. $\quad$ Linares, L.; Garcia-Goez, J.F.; Cervera, C.; Almela, M.; Sanclemente, G.; Cofan, F.; Ricart, M.J.; Navasa, M.; Moreno, A. Early bacteremia after solid organ transplantation. Transplant. Proc. 2009, 41, 2262-2264. [CrossRef]

6. Bodro, M.; Sabe, N.; Tubau, F.; Liado, L.; Baliellas, C.; Gonzales-Costello, J.; Cruzado, J.M.; Carratala, J. Extensively drug-resistant Pseudomonas aeruginosa bacteremia in solid organ transplant recipients. Transplantation 2015, 99, 616-622. [CrossRef]

7. Bodro, M.; Sabe, N.; Tubau, F.; Liado, L.; Baliellas, C.; Roca, J.; Cruzado, J.M.; Carratala, J. Risk factors and outcomes of bacteremia caused by drug-resistant ESKAPE pathogens in solid-organ transplant recipients. Transplantation 2013, 96, 843-849. [CrossRef]

8. Johnson, L.E.; D'Agata, E.M.; Paterson, D.L.; Clarke, L.; Qureshi, Z.A.; Potoski, B.A.; Peleg, A.Y. Pseudomonas aeruginosa bacteremia over a 10-year period: Multidrug resistance and outcomes in transplant recipients. Transpl. Infect. Dis. 2009, 11, 227-234. [CrossRef]

9. Silveira, F.P.; Marcos, A.; Kwak, E.J.; Husain, S.; Shapiro, R.; Thai, N.; McKurry, K.R.; Abu-Elmagd, K.; Paterson, D.L. Bloodstream infections in organ transplant recipients receiving alemtuzumab: no evidence of occurrence of organisms typically associated with profound T depletion. J. Infect. 2006, 53, 241-247. [CrossRef]

10. Caravaca-Fontan, F.; Jimenez-Alvaro, S.; Marcen-Letosa, R.; Fernandez-Rodriguez, A.; Rodriguez-Navarro, C.Q. Ceftazidime avibactam in urinary tract infections due to carbapenemase-producing Klebsiella in kidney transplantation. Nefrologia 2015, 35, 412-413. [CrossRef]

11. Deharvengt, S.J.; Tsongalis, G.J. Molecular assessment of human diseases in the clinical laboratory. In Molecular Pathology, 2nd ed.; Coleman, W., Tsongalis, G.J., Eds.; Elsevier Academic Press: London, UK, 2018; Volume 1, pp. 709-730.

12. Feikin, D.R.; Hammitt, L.L.; Murdoch, D.R.; O’Brien, K.L.; Scott, J.A.G. The enduring challenge of determining pneumonia etiology in children: considerations for future research priorities. Clin. Infect. Dis. 2017, 64, S188-S196. [CrossRef] [PubMed]

13. Baker, A.W.; Maziarz, E.K.; Arnold, C.J.; Johnson, M.D.; Workman, A.D.; Reynolds, J.M.; Perfect, J.R.; Alexander, B.D. Invasive Fungal Infection After Lung Transplantation: Epidemiology in the Setting of Antifungal Prophylaxis. Clin. Infect. Dis. 2020, 70, 30-39. [CrossRef] [PubMed]

14. Clancy, C.J.; Nguyen, M.H. Finding the missing 50\% of invasive candidiasis: how nonculture diagnostics will improve understanding of disease spectrum and transform patient care. Clin. Infect. Dis. 2013, 56, 1284. [CrossRef] [PubMed]

15. Rogers, G.B.; Hart, C.A.; Mason, J.R.; Hughes, M.; Walshaw, M.J.; Bruce, K.D. Bacterial diversity in cases of lung infection in cystic fibrosis patients: $16 \mathrm{~S}$ ribosomal DNA (rDNA) length polymorphism profiling. J. Clin. Microbiol. 2003, 41, 3548-3558. [CrossRef] [PubMed]

16. Filkins, L.M.; O' Toole, G. Cystic fibrosis lung infections: Polymicrobial, complex, and hard to treat. PLoS Pathog. 2015, 11, e1005258. [CrossRef] [PubMed]

17. Price, L.B.; Hungate, B.A.; Koch, B.J.; Davis, G.S.; Liu, C.M. Colonizing opportunistic pathogens (COPs). The beasts in all of us. PLoS Pathog. 2017, 13, e1006369. [CrossRef] [PubMed]

18. Floto, A.R.; Olivier, K.N.; Saiman, L.; Daley, C.L.; Herrmann, J.L.; Nick, J.A.; Noone, P.G.; Bilton, D.; Corris, P.; Gibson, R.L.; et al. US Cystic Fibrosis Foundation and European Cystic Fibrosis Society consensus recommendations for the management of non-tuberculous mycobacteria in individuals with cystic fibrosis. Thorax 2016, 71, i1-i22. [CrossRef]

19. Croxatto, A.; Prodhom, G.; Greub, G. Application of mass spectrometry in clinical diagnostic microbiology. FEMS Mocrobiol. Rev. 2012, 36, 380-407. [CrossRef]

20. Antibacterial Resistance Leadership Group. ARLG scientific agenda. Available online: www.arlg.org. (accessed on 31 January 2020).

21. Suarez, N.M.; Bunsow, E.; Falsey, A.R.; Walsh, E.E.; Mejias, A.; Ramilo, O. Superiority of transcriptional profiling over procalcitonin for distinguishing bacterial from viral lower respiratory tract infections in hospitalized adults. J. Infect. Dis. 2015, 212, 213-222. [CrossRef] 
22. Bhattacharya, S.; Rosenberg, A.F.; Peterson, D.R.; Grzesik, K.; Baran, A.M.; Ashton, J.M.; Gill, S.R.; Corbett, A.M.; Holden-Wiltse, J.; Topham, D.J.; et al. Transcriptomic biomarkers to discriminate bacterial from nonbacterial infection in adults hospitalized with respiratory illness. Sci. Rep. 2017, 7, 6548. [CrossRef]

23. Tsalik, E.L.; Henao, R.; Nichols, M.; Burke, T.; Ko, E.R.; McClain, M.T.; Hudson, L.L.; Mazur, A.; Freeman, D.H.; Veldman, T.; et al. Host gene expression classifiers diagnose acute respiratory illness etiology. Sci. Transl. Med. 2016, 8, 322ra11. [CrossRef] [PubMed]

24. Golfieri, R.; Giampalma, E.; Morselli Labate, A.M.; d’Arienzo, P.; Jovine, E.; Grazi, G.L.; Mazziotti, A.; Maffei, M.; Muzzi, C.; Tancioni, S.; et al. Pulmonary complications of liver transplantation: Radiological appearance and statistical evaluation of risk factors in 300 cases. Eur. Radiol. 2003, 10, 1169-1183. [CrossRef] [PubMed]

25. Rao, K.H.; Jha, R.; Narayan, G.; Sinha, S. Opportunistic infections following renal transplantation. Indian J. Med. Microbiol. 2002, 20, 47-49. [PubMed]

26. Loinaz, C.; Kato, T.; Nishida, S.; Weppler, D.; Levi, D.; Dowdy, L.; Madariaga, J.; Nery, J.R.; Vianna, R.; Mittal, N. Bacterial infections after intestine and multivisceral transplantation. Transplant. Proc. 2003, 35, 1929-1930. [CrossRef]

27. Bonvillain, R.W.; Valentine, V.G.; Lombard, G. Post-operative infections in cystic fibrosis and non-cystic fibrosis patients after lung transplantation. J. Heart Lung Transplant. 2007, 26, 890-897. [CrossRef]

28. Husain, S.; Paterson, D.L.; Studer, S.M.; Crespo, M.; Pilewski, J.; Durkin, M.; Wheat, J.L.; Johnson, B.; Mclaughlin, L.; Bentsen, C.; et al. Aspergillus galactomannan antigen in the bronchoalveolar lavage fluid for the diagnosis of invasive aspergillosis in lung transplant recipients. Transplantation 2007, 83, 1330-1336. [CrossRef]

29. Campos, S.; Caramori, M.; Teixeira, R.; Afonso, J., Jr.; Carraro, R.; Strabelli, T.; Samano, M.; Pêgo-Fernandes, P.; Jatene, F. Bacterial and fungal pneumonias after lung transplantation. Transplant. Proc. 2008, 40, 822-824. [CrossRef]

30. Mota, P.C.; Vaz, A.P.; Ferreira, I.C.; Alfonso, J.; Carraro, L.; Strabelli, T.; Samano, M.; Pego-Fernandes, P.; Jatene, F. Lung and renal transplantation. Rev. Port. De Pneumol. 2009, 15, 1073-1099. [CrossRef]

31. Kupeli, E.; Ulubay, G.; Colak, T.; Ozdemirel, T.S.; Ozyurek, B.A.; Akcay, S.; Haberal, M. Pulmonary Complications in Renal Recipients After Transplantation. Transplant. Proc. 2011, 43, 551-553. [CrossRef]

32. Qin, J.; Xu, J.; Dong, Y.; Tang, W.; Wu, B.; An, Y.; Shan, H. High-resolution CT findings of pulmonary infections after orthotopic liver transplantation in 453 patients. Br. J. Rad 2012, 85, e959-e965. [CrossRef]

33. Eyuboglu, F.O.; Küpeli, E.; Bozbas, S.S.; Ozen, Z.E.; Akkurt, E.S.; Aydogan, C.; Ulubay, G.; Akcay, S.; Haberal, M. Evaluation of pulmonary infections in solid organ transplant patients: 12 years of experience. Transplant. Proc. 2013, 45, 3458e3461. [CrossRef]

34. Kim, S.Y.; Shin, J.A.; Cho, E.N.; Byun, M.K.; Kim, H.J.; Ahn, C.M.; Haam, S.J.; Lee, D.Y.; Paik, H.C.; Chang, Y.S. Late respiratory infection after lung transplantation. Tuberc. Respir. Dis. 2013, 74, 63-69. [CrossRef]

35. Hekimoglu, K.; Tezcan, S.; Coskun, M.; Dogrul, M.I.; Moray, G.; Haberal, M. MDCT evaluation of early pulmonary infection types after liver transplantation. Transplant. Proc. 2015, 47, 473e477. [CrossRef]

36. Li, J.J. Clinical characteristics and treatment experience report of severe pulmonary infection after renal transplantation. Pak. J. Pharm Sci. 2015, 28, 1559-1562.

37. Shah, S.K.; McAnally, K.J.; Seoane, L.; Lombard, G.A.; LaPlace, S.G.; Lick, S.; Dhillon, G.S.; Valentine, V.G. Analysis of pulmonary non-tuberculous mycobacterial infections after lung transplantation. Transpl. Infect. Dis. 2016, 18, 585-591. [CrossRef]

38. Aspelund, A.S.; Hammarström, H.; Inghammar, M. Microbiological findings in bronchoalveolar lavage fluid from lung transplant patients in Sweden. Transpl. Infect. Dis. 2018, 20, e12973. [CrossRef]

39. Magnusson, J.; Westin, J.; Andersson, L.M.; Lindh, M.; Brittain-Longo, R.; Norden, R.; Riise, G.C. Viral respiratory tract infection during the first postoperative year is a risk factor for chronic rejection after lung transplantation. Transplant. Direct 2018, 4, e370. [CrossRef]

40. Onyearugbulem, C.; Williams, L.; Zhu, H.; Gazzaneo, M.C.; Melicoff, E.; Das, S.; Coss-Bu, J.; Lam, F.; Mallory, G.; Munoz, F.M. Risk factors for infection after pediatric lung transplantation. Transpl. Infect. Dis. 2018, 20, e13000. [CrossRef]

41. Tachibana, K.; Okada, Y.; Matsuda, Y.; Miyoshi, K.; Oto, T.; Chen-Yoshikawa, T.F.; Date, H.; Minami, M.; Okumura, M.; Iwasaki, A. Nontuberculous mycobacterial and Aspergillus infections among cadaveric lung transplant recipients in Japan. Respir Investig. 2018, 56, 243-248. [CrossRef] 
42. Griffith, D.E.; Aksamit, T.; Brown-Elliott, B.; Catanzaro, A.; Daley, C.; Gordin, F.; Holland, S.M.; Horsburgh, R.; Huitt, G.; iademarco, M.F.; et al. An official ATS/IDSA statement: diagnosis, treatment, and prevention of nontuberculous mycobacterial disease. Am. J. Respir Crit Care Med. 2007, 175, 367-416. [CrossRef]

43. De Pauw, B.; Walsh, T.J.; Donnelly, J.P.; Stevens, D.A.; Edwards, J.E.; Calandra, T.; Pappas, P.G.; Maertens, J.; Lortholary, O.; Kauffman, C.A.; et al. Revised definitions of invasive fungal disease from the European organization for research and treatment of cancer/invasive fungal infections cooperative group and the National Institute of Allergy and Infectious Diseases Mycoses Study Group (EORTC/MSG) Consensus Group. Clin. Infect. Dis. 2008, 46, 1813-1821. [PubMed]

44. Dela Cruz, C.S.; Wunderink, R.G.; Christiani, D.; Cormier, S.A.; Crothers, K.; Doerschuk, C.M.; Evans, S.E.; Goldstein, D.R.; Khatri, P.; Kobzik, L.; et al. Future research in pneumonia. Am. J. Resp. Crit. Care Med. 2018, 198, 256-263. [CrossRef] [PubMed]

45. Hammitt, L.L.; Feikin, D.R.; Scott, J.A.G.; Zeger, S.L.; Murdoch, D.R.; O’Brien, K.L.; Knoll, M.D. Addressing the analytical challenges of cross-sectional pediatric pneumonia etiology data. Clin. Infect. Dis. 2017, 64, S197-S204. [CrossRef]

46. Knoll, M.D.; Fu, W.; Shi, Q.; Prosperi, C.; Wu, Z.; Hammitt, L.L.; Feikin, D.R.; Baggett, H.C.; Howie, S.R.C.; Scott, J.A.G. Bayesian estimation of pneumonia etiology: epidemiologic considerations and applications to the Pneumonia Etiology Research for Child study. Clin. Infect. Dis. 2017, 64, S213-S227. [CrossRef] [PubMed]

47. O’Brien, K.L.; Baggett, H.C.; Brooks, W.A.; Feikin, D.R.; Hammitt, L.L.; Howie, S.R.C.; Knoll, M.D.; Kotloff, K.L.; Levine, O.S.; Madhi, S.A.; et al. Introduction to the epidemiologic considerations, analytic methods, and foundational results from the Pneumonia Etiology Research for Child study. Clin. Infect. Dis. 2017, 64, S179-S184.

48. Aguado, J.M.; Silva, J.T.; Fernandez-Ruiz, M.; Cordero, E.; Fortun, J.; Gudiol, C.; Martinez-Martinez, L.; Vidal, E.; Almenar, L.; Almirante, B.; et al. Management of multidrug resistant Gram-negative bacilli infections in solid organ transplant recipients: SET/GESITRA-SEIMC/REIPI recommendations. Transplant. Rev. 2018, 32, 36-57. [CrossRef]

49. Oriol, I.; Sabe, N.; Simonetti, A.F.; Llado, L.; Manonelles, A.; Gonzales, J.; Tubau, F.; Carratala, J. Changing trends in the aetiology, treatment and outcomes of bloodstream infection occurring in the first year after solid organ transplantation: A single-centre prospective cohort study. Transpl. Int. 2017, 30, 903-913. [CrossRef]

50. Biderman, P.; Bugaevsky, Y.; Ben-Zvi, H.; Bishara, J.; Goldberg, E. Multidrug-resistant Acinetobacter baumannii infections in lung transplant patients in the cardiothoracic intensive care unit. Clin. Transplant. 2015, 29, 756-762. [CrossRef]

51. Prieto Amorin, J.; Lopez, M.; Rando, K.; Castelli, J.; Medina Presentado, J. Early Bacterial Pneumonia After Hepatic Transplantation: Epidemiologic Profile. Transplant. Proc. 2018, 50, 503-508. [CrossRef]

52. Husain, S.; Mooney, M.L.; Danziger-Isakov, L.; Mattner, F.; Singh, N.; Avery, R.; Ison, M.; Humar, A.; Padera, R.F.; Lawler, L.P.; et al. A 2010 working formulation for the standardization of definitions of infections in cardiothoracic transplant recipients. J. Heart Lung Transplant. 2011, 30, 361-374. [CrossRef]

53. Vadnerkar, A.; Clancy, C.J.; Celik, U.; Yousem, S.A.; Mitsani, D.; Toyoda, Y.; Nguyen, M.L.; Kwak, E.J.; Pilewski, J.; Silveira, F.P.; et al. Impact of mold infections in explanted lungs on outcomes of lung transplantation. Transplantation 2010, 89, 253-260. [CrossRef] [PubMed]

54. Yusen, R.D.; Edwards, L.B.; Kucheryavaya, A.Y.; Yousem, S.A.; Mitsani, D.; Toyoda, Y.; Nguyen, M.L.; Kwak, E.J.; Pilewski, J.; Silveira, F.P.; et al. The registry of ISHLT: thirty-second official adult lung and heart-lung transplantation report 2015. Focus theme: early graft failure. J. Heart Lung Transplant. 2015, 34, 1264-1277. [CrossRef] [PubMed]

55. Vos, R.; Vanaudenaerde, B.M.; Dupont, L.J.; Van Raemdonck, D.E.; Verleden, G.M. Transient airway colonization is associated with airway inflammation after lung transplantation. Am. J. Transplant. 2007, 7, 1278-1287. [CrossRef] [PubMed]

56. Botha, P.; Archer, L.; Anderson, R.L.; Lordan, J.; Dark, J.H.; Corris, P.A.; Gould, K.; Fisher, A.J. Pseudomonas aeruginosa colonization of the allograft after lung transplantation and the risk of bronchiolitis obliterans syndrome. Transplantation 2008, 85, 771-774. [CrossRef]

57. Vos, R.; Vanaudenaerde, B.M.; Geudens, N.; Dupont, L.J.; Van Raemdonck, D.E.; Verleden, G.M. Pseudomonal airway colonisation: risk factor for bronchiolitis obliterans syndrome after lung transplantation? Eur. Respir J. 2008, 31, 1037-1045. [CrossRef] 
58. Vos, R.; Vanaudenaerde, B.M.; De Vleeschauwer, S.I.; Van Raemdonck, D.E.; Dupont, L.J.; Verleden, G.M. De novo or persistent pseudomonal airway colonization after lung transplantation: Importance for bronchiolitis obliterans syndrome? Transplantation 2008, 86, 624-625. [CrossRef]

59. Gottlieb, J.; Mattner, F.; Weissbrodt, H.; Dierich, M.; Fuehner, T.; Strueber, M.; Simon, A.; Welte, T. Impact of graft colonization with gram-negative bacteria after lung transplantation on the development of bronchiolitis obliterans syndrome in recipients with cystic fibrosis. Respir Med. 2009, 103, 743-749. [CrossRef]

60. Palacio, F.; Reyes, L.F.; Levine, D.J.; Sanchez, J.F.; Angel, L.F.; Fernandez, J.F.; Levine, S.M.; Rello, J.; Abedi, A.; Restrepo, M.I. Understanding the Concept of Health Care-Associated Pneumonia in Lung Transplant Recipients. Chest 2015, 148, 516-522. [CrossRef]

61. Aguilar-Guisado, M.; Givalda, J.; Ussetti, P.; Ramos, A.; Morales, P.; Blanes, M.; Bou, G.; de la Torre-Cisneros, J.; Roman, A.; Borro, J.M. Pneumonia after lung transplantation in the RESITRA cohort: A multicenter prospective study. Am. J. Transplant. 2007, 7, 1989-1996. [CrossRef]

62. Walter, S.; Gudowius, P.; Bosshammer, J.; Romling, U.; Weissbrodt, H.; Schurmann, W.; von der Hardt, H.; Tummler, B. Epidemiology of chronic Pseudomonas aeruginosa infections in the airways of lung transplant recipients with cystic fibrosis. Thorax 1997, 52, 318-321. [CrossRef]

63. Takeda, S.; Nakai, T.; Wakai, Y.; Ikeda, F.; Hatano, K. In vitro and in vivo activities of a new cephalosporin, FR264205, against Pseudomonas aeruginosa. Antimicrob. Agents Chemother. 2007, 51, 826-830. [CrossRef] [PubMed]

64. Karlowsky, J.A.; Kazmierczak, K.M.; de Jonge, B.L.M.; Hackle, M.A.; Sahm, D.F.; Bradford, P.A. In vitro activity of axtreonam-avibactam against Enterobacteriacae and Pseudomonas aeruginosa isolated by clinical laboratories in 40 countries from 2012 to 2015. Antimicrob. Agents Chemother. 2017, 61, e00472-17. [CrossRef] [PubMed]

65. Bowers, D.R.; Liew, Y.X.; Lye, D.C.; Kwa, A.L.; Hsu, L.Y.; Tam, V.H. Outcomes of appropriate empiric combination versus monotherapy for Pseudomonas aeruginosa bacteremia. Antimicrob. Agents Chemother. 2013, 57, 1270-1274. [CrossRef] [PubMed]

66. Pena, C.; Suarez, C.; Ocampo-Sosa, A.; Murillas, J.; Almirante, B.; Pomar, V.; Aguilar, M.; Granados, A.; Calbo, E.; Rodriguez-Bano, J.; et al. Effect of adequate single-drug vs combination antimicrobial therapy on mortality in Pseudomonas aeruginosa bloodstream infections: A post hoc analysis of a prospective cohort. Clin. Infect. Dis. 2013, 57, 208-216. [CrossRef]

67. Hu, Y.; Li, L.; Li, W.; Xu, H.; He, P.; Yan, X.; Dai, H. Combination antibiotic therapy versus monotherapy for Pseudomonas aeruginosa bacteraemia: A meta-analysis of retrospective and prospective studies. Int. J. Antimicrob. Agents 2013, 42, 492-496. [CrossRef]

68. Vardakas, K.Z.; Tansarli, G.S.; Bliziotis, I.A.; Falagas, M.E. Beta-lactam plus aminoglycoside or fluoroquinolone combination versus beta-lactam monotherapy for Pseudomonas aeruginosa infections: A meta-analysis. Int. J. Antimicrob. Agents 2013, 41, 301-310. [CrossRef]

69. Kitazono, H.; Rog, D.; Grim, S.A.; Clark, N.M.; Reid, G.E. Acinetobacter baumannii infection in solid organ transplant recipients. Clin. Transplant. 2015, 29, 227-232. [CrossRef]

70. Nie, X.M.; Huang, P.H.; Ye, Q.F.; Wan, Q.Q. The Distribution, Drug Resistance, and Clinical Characteristics of Acinetobacter baumannii Infections in Solid Organ Transplant Recipients. Transplant. Proc. 2015, 47, 2860-2864. [CrossRef]

71. Garnacho-Montero, J.; Ortiz-Leyba, C.; Jime'nez-Jime'nez, F.J.; Barrero-Almodovar, A.E.; Garcia-Garmendia, J.L.; Bernabeu-Wittel, M.; Gallego-Lara, S.L.; Madrazo-Osuna, J. Treatment of multidrug-resistant Acinetobacter baumannii ventilator associated pneumonia (VAP) with intravenous colistin: A comparison with imipenemsusceptible VAP. Clin. Infect. Dis. 2003, 36, 1111-1118. [CrossRef]

72. Kallel, H.; Hergafi, L.; Bahloul, M.; Hakim, A.; Dammak, H.; Chelly, H.; Hamida, C.B.; Chaari, A.; Rekik, N.; Bouaziz, M. Safety and efficacy of colistin compared with imipenem in the treatment of ventilator-associated pneumonia: A matched case-control study. Intensive Care Med. 2007, 33, 1162-1167. [CrossRef]

73. Qureshi, Z.A.; Hittle, L.E.; O’Hara, J.A.; Rivera, J.I.; Syed, A.; Shields, R.K.; Pasculle, A.W.; Ernst, R.K.; Doi, Y. Colistin-resistant Acinetobacter baumannii: Beyond carbapenem resistance. Clin. Infect. Dis. 2015, 60, 1295-1303. [CrossRef] [PubMed] 
74. Shields, R.K.; Clancy, C.J.; Gillis, L.M.; Kwak, E.J.; Silveira, F.P.; Massih, R.C.; Eschenauer, G.A.; Potoski, B.A.; Nguyen, M.H. Epidemiology, clinical characteristics and outcomes of extensively drug-resistant Acinetobacter baumannii infections among solid organ transplant recipients. PLoS ONE 2012, 7, e52349-58. [CrossRef] [PubMed]

75. Lee, H.J.; Bergen, P.J.; Bulitta, J.B.; Tsuji, B.; Forrest, A.; Nation, R.; Li, J. Synergistic activity of colistin and rifampin combination against multi-drug resistant Acinetobacter baumanni in an in vitro pharmacokinetic/pharmacodynamic model. Antimicrob. Agents Chemother. 2013, 57, 3738-3745. [CrossRef] [PubMed]

76. Durante-Mangoni, E.; Signoriello, G.; Andini, R.; Mattei, A.; De Cristoforo, M.; Murino, P.; Bassetti, M.; Malacarne, P.; Petrosillo, N.; Galdieri, N.; et al. Colistin and rifampicin compared with colistin alone for the treatment of serious infections due to extensively drug-resistant Acinetobacter baumannii: A multicenter, randomized clinical trial. Clin. Infect. Dis. 2013, 57, 349-358. [CrossRef]

77. Busey, K.; Ferreira, J.; Aldridge, P.; Johnson, D.; Guzman, N.; Jankowski, C.A. Treatment efficacy of ampicillin/sulbactam in comparison to alternative betalactams for severe Acinetobacter baumanii infections. Infect. Dis. 2016, 48, 775-777. [CrossRef]

78. Zilberg, M.D.; Kollef, M.H.; Shorr, A.F. Secular trends in Acinetobacter baumanii resistance in respiratory and bloodstream specimens in the United States, 2003 to 2012. A survey study. J. Hosp. Med. 2016, 11, 21-26. [CrossRef]

79. Garnacho-Montero, J.; Dimopoulos, G.; Poulakou, G.; Akova, M.; Cisneros, J.M.; De Waele, J.; Petrosillo, N.; Seifert, H.; Timsit, J.F.; Vila, J.; et al. Task force on management and prevention of Acinetobacter baumannii infections in the ICU. Intensive Care Med. 2015, 41, 2057-2075. [CrossRef]

80. Magiorakos, A.P.; Suentes, C.; Monnet, D.L.; Gagliotti, C.; Heuer, O.E.; EARS-Net Coordination Group and EARS-Net Participants. The rise of carbapenem resistance in Europe: just the tip of the iceberg? Antimicrob. Resist. Infect. Control. 2013, 2, 6. [CrossRef]

81. Giannella, M.; Bartoletti, M.; Campoli, C.; Rinaldi, M.; Coladonato, S.; Pascale, R.; Tedeschi, S.; Ambretti, S.; Cristini, F.; Tumietto, F.; et al. The impact of carbapenemase-producing Enterobacteriaceae colonization on infection risk after liver transplantation: A prospective observational cohort study. Clin. Microbiol. Infect. 2019, in press. [CrossRef]

82. Bergamasco, M.D.; Barroso Barbosa, M.; de Oliveira Garcia, D.; Cipullo, R.; Moreira, J.C.; Baia, C.; Barbosa, V.; Abboud, C.S. Infection with Klebsiella pneumoniae carbapenemase (KPC)-producing K. pneumoniae in solid organ transplantation. Transpl. Infect. Dis. 2012, 14, 198-205. [CrossRef]

83. Shields, R.K.; Nguyen, M.H.; Chen, L.; Press, E.G.; Potoski, B.A.; Marini, R.V.; Doi, Y.; Kreiswirth, B.N.; Clancy, C.J. Ceftazidime-Avibactam Is Superior to Other Treatment Regimens against Carbapenem-Resistant Klebsiella pneumoniae Bacteremia. Antimicrob. Agents Chemother. 2017, 61, e00883-17. [CrossRef] [PubMed]

84. Tumbarello, M.; Trecarichi, E.M.; Corona, A.; De Rosa, F.G.; Bassetti, M.; Mussini, C.; Menichetti, F.; Viscoli, C.; Campoli, C.; Venditti, M.; et al. Efficacy of Ceftazidime-avibactam Salvage Therapy in Patients with Infections Caused by KPC-producing Klebsiella pneumoniae. Clin. Infect. Dis. 2019, 68, 355-364. [CrossRef] [PubMed]

85. Van Duin, D.; Lok, J.J.; Earley, M.; Cober, E.; Richter, S.S.; Perez, F.; Salata, R.A.; Kalayjian, R.C.; Watkins, R.R.; Doi, Y.; et al. Colistin Versus Ceftazidime-Avibactam in the Treatment of Infections Due to Carbapenem-Resistant Enterobacteriaceae. Clin. Infect. Dis. 2018, 66, 163-171. [CrossRef] [PubMed]

86. Mojica, M.F.; Ouellette, C.P.; Leber, A.; Becknell, M.B.; Ardura, M.I.; Perez, F.; Shimamura, M.; Bonomo, R.A.; Aitken, S.L.; Shelburne, S.A. Successful treatment of bloodstream infection due to metallo-beta-lactamase-producing Stenotrophomonas maltophilia in a renal transplant patient. Antimicrob. Agents Chemother. 2016, 60, 5130-5134. [CrossRef] [PubMed]

87. Jacobs, D.M.; DiTursi, S.; Ruh, C.; Sharma, R.; Claus, J.; Banjade, R.; Rao, G.G. Combination treatment with extended infusion ceftazidime/avibactam for a KPC-3-producing Klebsiella pneumonia bacteraemia in a kidney and pancreas transplant patient. Int. J. Antimicrob. Agents 2016, 48, 225-227. [CrossRef] [PubMed]

88. Peghin, M.; Maiani, M.; Castaldo, N.; Givone, F.; Righi, E.; Lechiancole, A.; Sartor, A.; Pea, F.; Livi, U.; Bassetti, M. Ceftolozane/tazobactam for the treatment of MDR Pseudomonas aeruginosa left ventricular assist device. Infection 2018, 46, 263-265. [CrossRef] 
89. Shields, R.K.; Nguyen, M.H.; Chen, L.; Press, E.G.; Kreiswirth, B.N.; Clancy, C.J. Pneumonia and Renal Replacement Therapy Are Risk Factors for Ceftazidime-Avibactam Treatment Failures and Resistance among Patients with Carbapenem-Resistant Enterobacteriaceae Infections. Antimicrob. Agents Chemother. 2018, 62, e02497. [CrossRef]

90. US Food and Drug Administration. New Release: FDA Approves New Antibacterial Drug to Treat Complicated Urinary Tract Infection as Part of Ongoing Efforts to Address Antimicrobial Resistance. Available online: https://www.fda.gov/news-events/press-announcements/fda-approves-new-antibacterialdrug-treat-complicated-urinary-tract-infections-part-ongoing-efforts (accessed on 1 December 2019).

91. Castanheira, M.; Huband, M.D.; Mendes, R.E.; Flamm, R.K. Meropenem-vaborbactam tested against contemporary Gram-negative isolates collected worldwide during 2014, including carbapenem resistant, KPC_producing, multidrug resistant, and extensively drug resistant Enterobacteriaceae. Antimicrob. Agents Chemother. 2017, 61, e00567. [CrossRef]

92. Castanheira, M.; Davis, A.P.; Mendes, R.E.; Serio, A.W.; Krause, K.M.; Flamm, R.K. In vitro activity of plazomicin against Gram-negative and Gram-positive isolates collected from U.S. hospitals and comparative activities of aminoglycosides against carbapenem-resistant Enterobacteriaceae and isolates carrying carbapenemase genes. Antimicrob. Agents Chemother. 2018, 62, e00313-e00318. [CrossRef]

93. Centers for Disease Control and Prevention. Antibiotic stewardship driver diagram and change package. 2012. Available online: www.cdc.gov (accessed on 1 December 2019).

94. Seo, S.K.; Lo, K.; Abbo, L.M. Current state of antimicrobial stewardship at solid organ and hematopoietic cell transplant centers in the United States. Infect. Control. Hosp. Epidemiol. 2016, 37, 1195-1200. [CrossRef]

95. Hamandi, B.; Husain, S.; Humar, A.; Papadimitropoulos, E.A. Impact of infectious disease consultation on the clinical and economic outcomes of solid organ transplant recipients admitted for infectious complications. Clin. Infect. Dis. 2014, 59, 1074-1082. [CrossRef] [PubMed]

96. So, M.; Mamdani, M.M.; Morris, A.M.; Lau, T.T.Y.; Broady, R.; Deotare, U.; Grant, J.; Kim, D.; Schimmer, A.D.; Schuh, A.C.; et al. Effect of an antimicrobial stewardship programme on antimicrobial utilisation and costs in patients with leukaemia: A retrospective controlled study. Clin. Microbiol. Infect. 2018, 24, 882-888. [CrossRef] [PubMed]

97. Aitken, S.L.; Palmer, H.R.; Topal, J.E.; Gabardi, S.; Tichy, E. Call for antimicrobial stewardship in solid organ transplantation. Am. J. Transplant. 2013, 13, 2499. [CrossRef] [PubMed]

(C) 2020 by the authors. Licensee MDPI, Basel, Switzerland. This article is an open access article distributed under the terms and conditions of the Creative Commons Attribution (CC BY) license (http://creativecommons.org/licenses/by/4.0/). 